\title{
Pengaruh Aerasi Terhadap Pretreatment Eceng Gondok Oleh Phanerochaete Chrysosporium
}

\author{
${ }^{1)}$ Rully Septria; ${ }^{2)}$ Suryo Purwono; ${ }^{2)}$ Siti Syamsiah; ${ }^{3)}$ Eka Sari \\ ${ }^{1)}$ Magister Teknik Pengendalian Pencemaran Lingkungan \\ Jurusan Teknik Kimia Universitas Gadjah Mada, \\ ${ }^{2)}$ Jurusan Teknik Kimia Universitas Gadjah Mada, \\ ${ }^{3)}$ Jurusan Teknik Kimia Universitas Sultan Ageng Tirtayasa \\ ${ }^{11}$ Email: rully_septria@yahoo.com
}

\begin{abstract}
Abstrak
Eceng gondok (Eichornia Crassipe) memiliki potensi dapat dikonversi menjadi bioetanol. Pretreatment biologi dengan Phanerochaete Chrysosporium memerlukan waktu lama karena kurangnya pasokan oksigen untuk pertumbuhan P.Chrysosporium. Upaya untuk memenuhi kebutuhan oksigen dapat dibantu dengan aerasi. Variasi kecepatan aerasi yang digunakan $0 \mathrm{~L} / \mathrm{m}^{2}$.men sampai 30,10 L/m ${ }^{2}$.men. Sampel diambil setiap 4 hari selama 24 hari. Kecepatan aerasi 2,15 L/m ${ }^{2}$.men sampai dengan hari ke 24 menghasilkan degradasi lignin sebesar 0,3076 gram. Sedangkan kecepatan

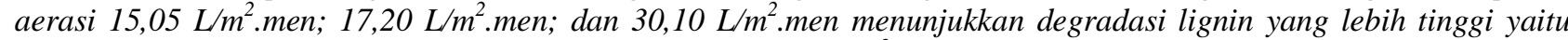
0,3374 gram; 0,4151 gram; dan 0,3944 gram. Aerasi 2,15 L/m ${ }^{2}$. men merupakan kecepatan optimum. Hal tersebut dapat dilihat dari hasil lignin yang paling rendah.
\end{abstract}

Kata Kunci : Aerasi, pretreatment, eceng gondok, lignoselulosa

\section{PENDAHULUAN}

Energi alternatif yang berasal dari biomassa tanaman merupakan upaya pendukung keberlanjutan pembangunan (Adelekan, 2012). Tanaman eceng gondok (Eichornia crassipes) merupakan sumber biomassa yang mendukung sebagai energi alternatif yang dapat dikonversi menjadi bioethanol (Zimmels et al., 2009., dan Chang, 2012).

Struktur lignin di degradasi melalui tahap awal yaitu pretreatment. Metode pretreatment diantaranya yaitu metode fisik, kimia dan biologi. Metode biologi memerlukan mikroorganisme aerob selama prosesnya. Pertumbuhan mikroorganisme yang berjalan lama menjadi tantangan metode biologi. Oksigen merupakan salah satu faktor yang berpengaruh terhadap pertumbuhan mikroorganisme. Diperlukan upaya untuk memenuhi kebutuhan oksigen pada mikroorganisme. Kebutuhan oksigen tersebut dapat dibantu dengan menggunakan aerasi yang dialirkan secara merata ke dalam reaktor.

Tujuan penelitian ini yaitu mempelajari pertumbuhan P.Chrysosporium terhadap variasi kecepatan aerasi pada pretreatment eceng gondok. Sehingga penelitian ini akan mendapat data degradasi 
lignin, produksi selulosa, dan hemiselulosa terhadap variasi kecepatan aerasi pada pretreatment eceng gondok secara biologi.

\section{METODE PENELITIAN}

Komponen eceng gondok sebelum pretreatment dapat dilihat pada Tabel 1. Berikut.

Tabel 1. Komponen Eceng Gondok

\begin{tabular}{ccc}
\hline Komponen & Kandungan $(\%)$ & Kandungan (gram) \\
\hline Selulosa & 27,27 & 4,090 \\
Hemiselulosa & 34,72 & 5,208 \\
Lignin & 7,98 & 1,226 \\
Lain-lain (protein, & 30,03 & 4,476 \\
lipid, abu) & & \\
\hline total & 100 & 15
\end{tabular}

a. Bahan

Bahan utama yang digunakan dalam penelitian ini adalah eceng gondok, Potatoe Dextrose Agar (PDA), Bahan carrier (Campuran grajen kayu sengon, bekatul dan jagung), cofactor $\left(\mathrm{MnSO}_{4}\right)$, molase, Jamur Phanerochaete Chrysosporium dan enzim selulase.

b. Alat

Alat penelitian yang digunakan dalam penelitian ini yaitu aerator, filter udara, erlenmeyer 500 $\mathrm{ml}$, dan gelas beker.

c. Persiapan Bahan Baku

Tahap awal pembuatan dan perkembang biakkan isolate jamur P.Chrysosporium dengan media Potatoe Dextrose Agar (PDA). Kemudian Eeceng gondok seberat 15 gram dengan ukuran 0,5 $\mathrm{cm}$, dimasukkan ke Erlenmeyer berukuran $500 \mathrm{ml}$. Kemudian ditambahkan $1 \% \mathrm{MnSO}_{4}, 2 \%$ molase dan $70 \%$ kandungan air dari berat total eceng gondok. Persentase yang digunakan dalam penelitian ini adalah nilai optimum yang telah dilakukan penelitian sebelumnya (Sari et al., 2011).

d. Cara Percobaan

Sampling dilakukan setiap 4 hari selama 24 hari. Data yang diteliti yaitu penentuan kadar lignin, selulosa dan hemiselulosa menggunakan metode Chesson-Data. Kadar jamur P.Chrysosporium dianalisis menggunakan metode Kjeldhal. 
Kecepatan aerasi yang digunakan dapat diukur dengan menggunakan alat air flow meter. Supaya tidak mengalami kerusakkan pada pertumbuhan jamur, kecepatan aerasi yang diberikan dipertimbangkan berdasarkan gejolak yang terjadi didalam reaktor.

Luas permukaan eceng gondok digunakan untuk mengetahui luas yang dialiri oksigen. Dapat dihitung dengan luas permukaan tabung. Eceng gondok yang digunakan sebanyak 15 gram. Diameter dan tinggi diketahui dari ukuran potongan eceng gondok yang telah diseragamkan. Eceng gondok sebanyak 15 gram memiliki jumlah 370 potong dengan ukuran yang sebesar $0,5 \mathrm{~cm}$, diketahui luas permukaannya $2323,6 \mathrm{~cm}^{2}$ atau $0,23 \mathrm{~m}^{2}$.

\section{HASIL DAN PEMBAHASAN}

\section{1. Pengaruh aerasi terhadap pertumbuhan P.Chrysosporium}

Hubungan variasi kecepatan aerasi dengan pertumbuhan P.Chrysosporium dapat dilihat pada Gambar 1 berikut.

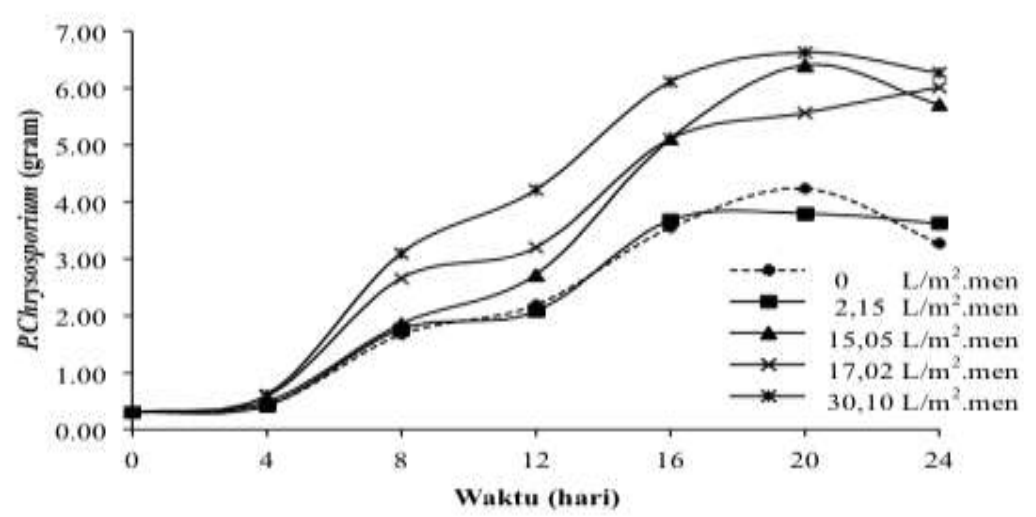

Gambar 1. Pengaruh Aerasi terhadap P.Chrysosporium

Berdasarkan Gambar 1. kandungan P.Chrysosporium mula-mula sebelum pretreatment sebesar 0,3 gram. Kemudian menghasilkan jumlah maksimal sampai dengan hari ke 20 untuk masingmasing aerasi sebesar 4,2326 gram; 4,8458 gram; 6,8412 gram; 5,5628 gram; dan 6,6252 gram. Pada hari ke 20 menunjukkan bahwa terpenuhinya nutrisi untuk P.Chrysosporium (Herliyana et al., 2011). Kemudian hari ke 24 jumlah P.Chrysosporium berkurang. Faktor terhentinya aktivitas tersebut dapat disebabkan karena kurangnya sumber bahan makanan dan terjadi akumulasi P.Chrysosporium yang bersifat toksik terhadap jasadnya, maupun terjadi karena kombinasi keadaan tersebut. 
Biomassa dapat bertambah dengan kecepatan aerasi yang meningkat (Bellido et al., 2013). Jumlah udara yang tersedia selama pretreatment dapat mendukung pertumbuhan P.Chrysosporium (Millati dan Cahyanto, 2012). Supaya tidak terjadi kerusakkan pada pertumbuhan jamur, kecepatan aerasi yang diberikan dipertimbangkan berdasarkan gejolak yang terjadi didalam reaktor.

\section{2. Pengaruh aerasi terhadap degradasi lignin}

Variasi kecepatan aerasi terhadap degradasi lignin dapat dilihat pada Gambar 2 berikut.

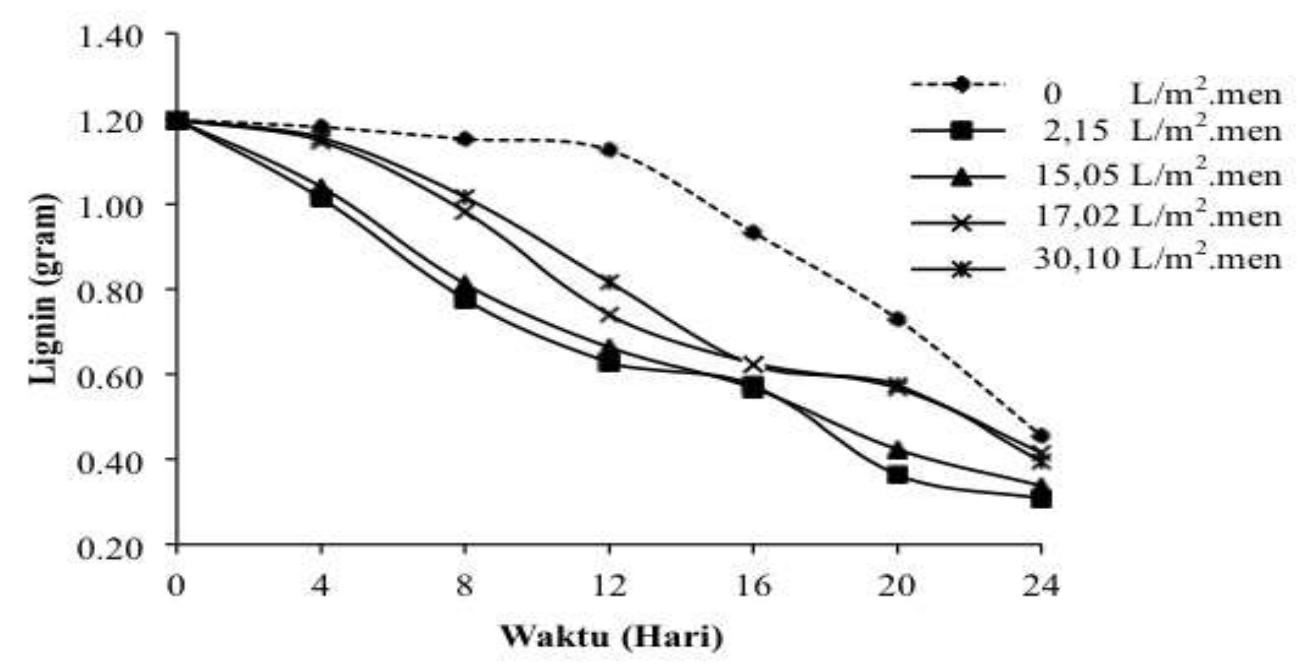

Gambar 2. Pengaruh aerasi terhadap degradasi lignin

Semua variasi kecepatan memiliki kandungan lignin yang berkurang sampai dengan hari ke 24 . Diantaranya untuk variasi kecepatan aerasi $0 \mathrm{~L} / \mathrm{m}^{2}$.men; $2,15 \mathrm{~L} / \mathrm{m}^{2}$.men; $15,05 \mathrm{~L} / \mathrm{m}^{2}$.men; 17,20 $\mathrm{L} / \mathrm{m}^{2}$.men dan $30,10 \mathrm{~L} / \mathrm{m}^{2}$.men masing-masing adalah 0,4545 gram; 0,3076 gram; 0,3374 gram; 0,4151 gram dan 0,3944 gram.

Degradasi lignin merupakan hal utama yang dipertimbangkan pada pretreatment (Chang, 2012). Pretreatment yang baik yaitu yang dapat memaksimalkan degradasi lignin sehingga tidak mengganggu kinerja proses selanjutnya (Limayem and Ricke, 2012). Penelitian ini menghasilkan jumlah lignin terdegradasi dengan baik pada kecepatan $2,15 \mathrm{~L} / \mathrm{m}^{2} . \mathrm{men}$. 


\section{3. Pengaruh aerasi terhadap selulosa}

Selulosa merupakan komponen yang diminimalisir terdegradasi selama pretreatment. Pengaruh aerasi terhadap selulosa yang dihasilkan dengan berbagai variasi kecepatan dapat dilihat pada Gambar 3.

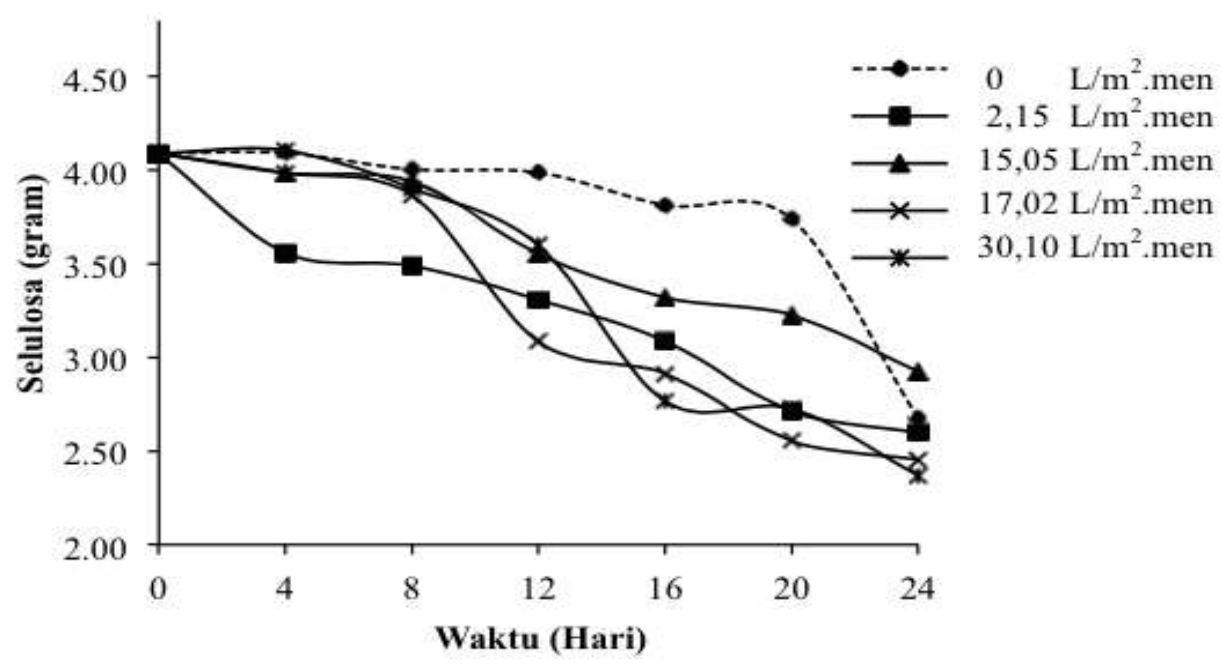

Gambar 3. Pengaruh Aerasi terhadap Selulosa

Penelitian ini menghasilkan jumlah selulosa berbanding terbalik dengan kecepatan aerasi. Selulosa ikut terdegradasi dengan meningkatnya kecepatan aerasi yang diberikan. Kandungan selulosa mula-mula sebelum pretreatment untuk semua aerasi sebesar 4,091 gram. Kemudian degradasi selulosa semakin meningkat dengan bertambahnya waktu sampai dengan hari ke 24 . Variasi kecepatan aerasi $0 \mathrm{~L} / \mathrm{m}^{2}$.men; $2,15 \mathrm{~L} / \mathrm{m}^{2}$.men; 15,05 L/m ${ }^{2}$.men; 17,20 L/m $\mathrm{m}^{2}$.men dan $30,10 \mathrm{~L} / \mathrm{m}^{2}$.men masing-masing memiliki kandungan selulosa sebesar 2,674 gram; 2,598 gram; 2,925 gram; 2,454 gram dan 2,370 gram.

Hasil terbaik untuk selulosa dengan mempertimbangkan degradasi lignin terdapat pada kecepatan $2,15 \mathrm{~L} / \mathrm{m}^{2}$.men. Selulosa yang banyak terdegradasi pada kecepatan $30,10 \mathrm{~L} / \mathrm{m}^{2}$.men berhubungan dengan P.Chrysosporium dan lignin. Dimana P.Chrysosporium mula-mula memecah dinding lignin. Setelah lignin terpecah maka pori-pori lignin akan terbuka lebar dan memudahkan selulosa untuk diakses (Haghihi et al., 2013). Akses lignin yang telah terbuka membuat P.Chrysosporium lebih memilih selulosa dengan rantai karbon lebih pendek dibandingkan lignin untuk dikonsumsi. Sehingga P.Chrysosporium menjadi pasif untuk mendegradasi lignin (Wibowo, 2010). 


\section{4. Pengaruh aerasi terhadap hemiselulosa}

Pengaruh aerasi terhadap hemiselulosa yang dihasilkan dengan berbagai variasi kecepatan dapat dilihat pada Gambar 4 berikut.

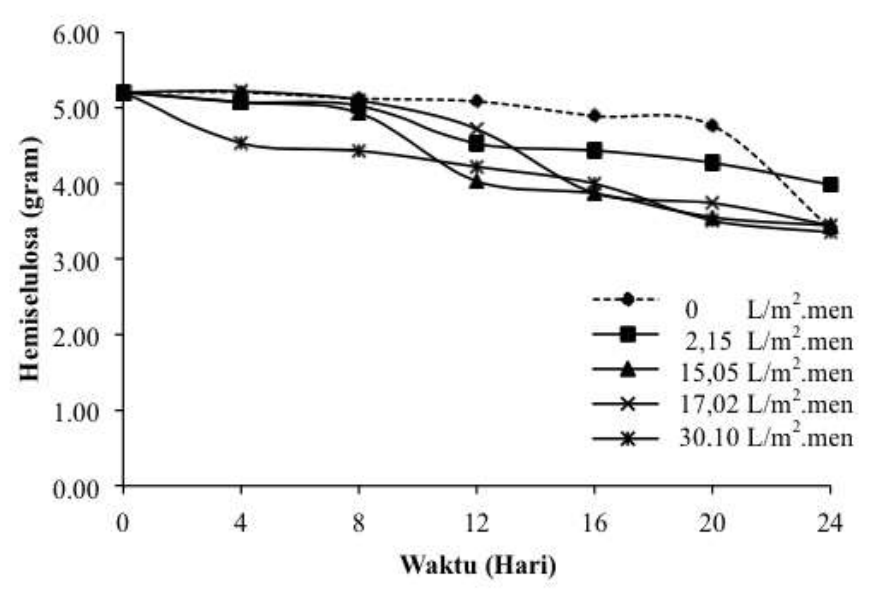

Gambar 4. Pengaruh Aerasi terhadap Hemiselulosa

Berdasarkan Gambar 4. kandungan selulosa mula-mula sebelum pretreatment sebesar 4.091 gram. Kemudian degradasi selulosa semakin meningkat dengan bertambahnya waktu sampai dengan hari ke 24. Variasi kecepatan aerasi $0 \mathrm{~L} / \mathrm{m}^{2}$.men; $2,15 \mathrm{~L} / \mathrm{m}^{2}$.men; $15,05 \mathrm{~L} / \mathrm{m}^{2}$.men; $17,20 \mathrm{~L} / \mathrm{m}^{2}$.men dan $30,10 \mathrm{~L} / \mathrm{m}^{2}$.men masing-masing memiliki kandungan selulosa sebesar 2,674 gram; 2,598 gram; 2,925 gram; 2,454 gram dan 2,370 gram.

Hemiselulosa yang terdegradasi lebih sedikit dibandingkan dengan lignin dan selulosa yang dapat dilihat pada Gambar 2 dan 3. Hemiselulosa terdegradasi secara minimal karena hemiselulosa memiliki rantai karbon lebih panjang dibandingkan selulosa. Sehingga dibandingkan dengan hemiselulosa, selulosa dengan rantai karbon lebih pendek lebih awal dikonsumsi oleh P.Chrysosporium (Wibowo, 2010).

\section{KESIMPULAN dan SARAN}

\subsection{Kesimpulan}

Aerasi dengan kecepatan 2,15 L/m².men merupakan kecepatan optimum dengan degradasi lignin yang paling maksimal dibandingkan dengan kecepatan aerasi lainnya sebesar 0,3076 
gram. Selain itu selulosa dan hemiselulosa yang terdegradasi dapat diminimalisir secara maksimal dengan hasil 2,598 gram dan 3,894 gram.

\subsection{Saran}

Penelitian ini diperlukan pengembangan analisis peralatan untuk mengetahui kandugan oksigen yang diperlukan P.Chrysosporium. Sehingga akan diperoleh nilai oksigen yang terkandung untuk mengetahui model kinetika transfer oksigen.

\section{DAFTAR PUSTAKA}

Adelekan, BA (2012). Development of a cellulosic ethanol production process integrating anaerobic digestion with biorefining. Journal Sciencedomain. Volume 2 (1). Page: 1-21.

Bellido, C., González-Benito, G., Coca, M., Lucas, S., and García-Cubero, M. T (2013). Influence of aeration on bioethanol production from ozonized wheat straw hydrolysates using Pichia stipitis. Journal Bioresource Technology. Volume 133. Page: 51-8.

Chang, G (2012). Pretreatment and fractionation of lignocellulosic biomass for production of biofuel and value-added products. Dissertation. Iowa State University.

Haghighi Mood, S., Hossein Golfeshan, A., Tabatabaei, M., Salehi Jouzani, G., Najafi, G. H., Gholami, M., and Ardjmand, M (2013). Lignocellulosic biomass to bioethanol, a comprehensive review with a focus on pretreatment. Renewable and Sustainable Energy Reviews. Volume 27. Page: 77-93.

Herliyana, E., Aisah, AR., dan Isroi (2011). Pretreatment with Phanerochaeta chrysosporium in paper sludge dilute acid hidrolisis. Journal Silvikultur Tropika. Volume 02 (03). Hal: 187193.

Limayem, A., and Ricke, S. C (2012). Lignocellulosic biomass for bioethanol production: Current perspectives, potential issues and future prospects. Progress in Energy and Combustion Science. Volume 38(4). Page: 449-467.

Millati, R dan Cahyanto, M (2012). Pengaruh ukuran potongan terhadap pertumbuhan jamur Pleurotus floridanus lipmc 996 dan hasil delignifikasi perlakuan pendahuluan tandan kosong kelapa sawit. Jurnal Teknologi Pertanian. Volume 32 (4). Page: 346-351.

Sari, E., Syamsiah, S., Sulistyo, S., and Muslikhin (2011). The Kinetic of Biodegradation Lignin in Water Hyacinth (Eichhornia Crassipes) by Phanerochaete Chrysosporium using Solid State 
Fermentation (SSF) Method for Bioethanol Production, Indonesia. World Academy of Science, Engineering and Technology Volume 5. Page: 182-185.

Wibowo, N (2010). Delignifikasi tandan kosong kelapa sawit oleh jamur Phanerochaete Chrysosporium untuk hidrolisis enzimatik. Tesis. Universitas Gajah Mada.

Zimmels, Y., Kirzhner, F., and Kadmon, A (2009). Effect of circulation and aeration on wastewater treatment by floating aquatic plants. Journal Separation and Purification Technology. Volume 66 (3). Page: 570-577. 